Dept. of Food Hygiene,

Fac. of Vet. Med., Assiut Univ.

\title{
PREVALENCE AND PUBLIC HEALTH HAZARD OF SUBCLINICAL MASTITIS IN GOATS AND SHEEP IN ASSIUT GOVERNORATE
}

(With 6 Tables and 2 Figures)

By

\section{T. EL-BASSIONY; ENAS EL-PRINCE; \\ KARIMA G. ABDEL-HAMEED; AMAL A. ABDEL-HALEEM* and ONSY A. SADEK * \\ *Assiut Animal Research Institute \\ (Received at 2/6/2008) \\ مدى انتثار والخطورة الصحية لمرض التهاب الضرع الغير ظاهري

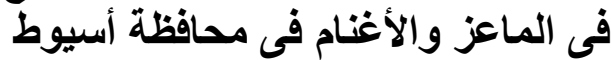

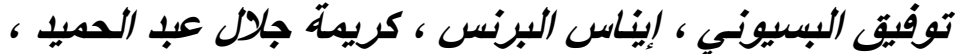

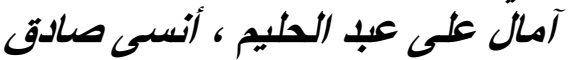

يعد التهاب الضرع الغير ظاهري من الأمر اض التي لها تأثير خطير على الناحية الاقتصادية

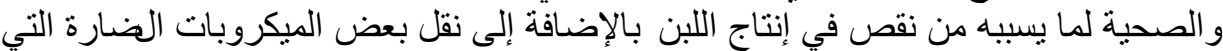

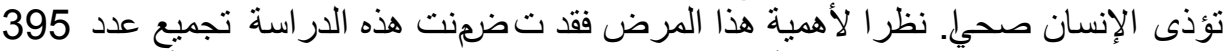

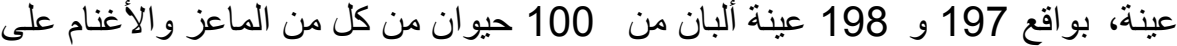

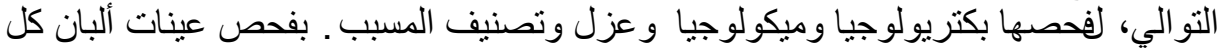

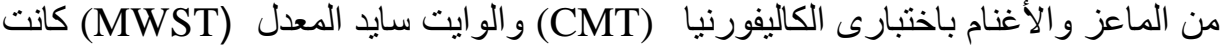

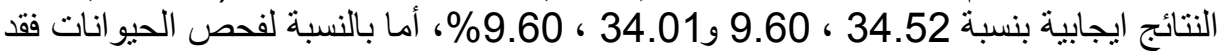

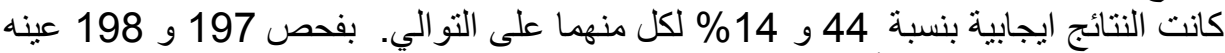

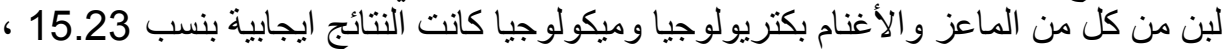

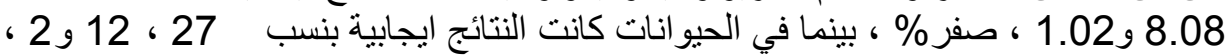

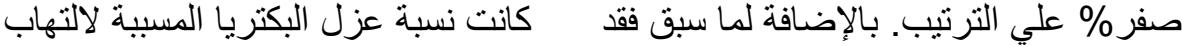

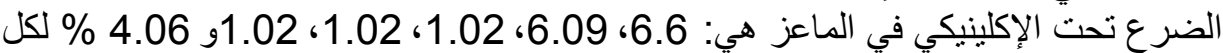

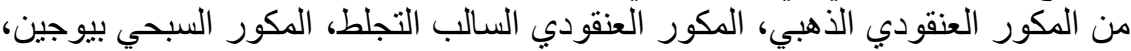

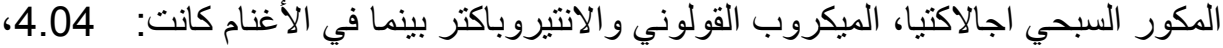

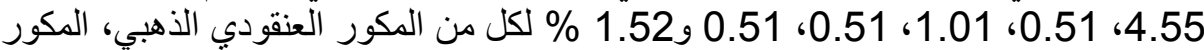

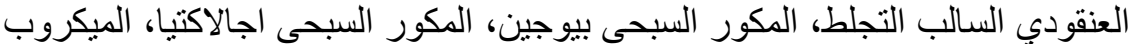

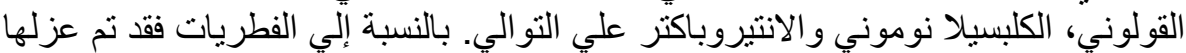

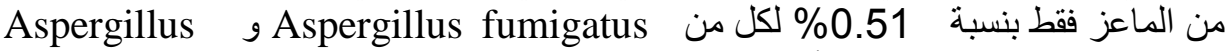
terreus. و قد ناقش البحث الأهمية الصحية و الوبائية والاقتصادية لمرض التهاب الضرع 


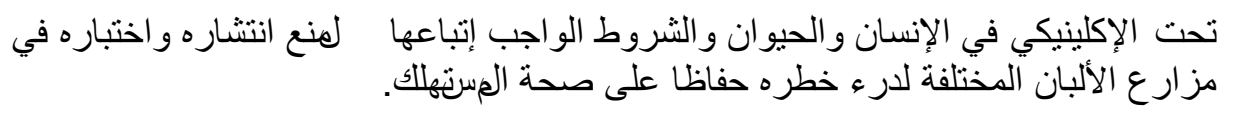

\section{SUMMARY}

A total number of 395 milk samples were collected from apparently healthy she-goats and ewes at different localities in Assiut Governorate, comprising 197 halves of milk samples from 100 lactating she-goats and 198 halves of milk samples from 100 lactating ewes. Our current results showed that $34.52 \& 9.60 \%$ and $34.01 \& 9.60 \%$ were positive in the examined she-goats and ewes halves by using California Mastitis Test (CMT) and Modified Whiteside Test (MWST), respectively. While, out of tested animals 44 and $14 \%$ were positive for each test, respectively. Moreover, screening tests used for detection of Subclinical Mastitis (SCM), one-half and two-halves of she-goats and ewes were affected in percentages of $20 \& 24$ and $9 \& 5 \%$, respectively. Furthermore, out of she-goats halves examined by bacteriological and mycological examinations, 15.23 and $1.02 \%$ were positive, while in case of ewe's halves, 8.08 and $0 \%$ were positive, respectively. Concerning 100 of each she-goats and ewes animals examined bacteriologically, 27 and 12\% were positive, respectively. While in case of mycological examination, $2 \%$ were positive in she-goats however, ewes gave negative results. The incidences of the isolated bacteria causing SCM in she-goat's milk samples were 6.60, 6.09, 1.02, 1.02, 1.02 and 4.06\% for Staph. aureus, coagulase negative Staphylococci (CNS), Str. pyogenes, Str. agalactiae, E. coli and Ent. spp., respectively. Whereas, in ewe's milk samples they were 4.04, 4.55, 0.51, 1.01, 0.51, 0.51 and 1.52\% for Staph. aureus, CNS, Str. pyogenes, Str. agalactiae, E. coli, Klebsiella pneumoniae and Ent. spp., respectively. The incidence of the isolated molds in she-goat's milk samples was $0.51 \%$ each for Aspergillus fumigatus and A. terreus. Recommendations were suggested to eradicate and control SCM in lactating goats and sheep.

Key words: Subclinical Mastitis, Screening Tests, Microbiological, Mycological examination, Goats and Sheep

\section{INTRODUCTION}

In small ruminant, mastitis, particularly in its subclinical and chronic forms, is a serious risk both to obtain milk of good hygienic quality and to farm profitability (Gonzalo, 1996). So, the study of mammary pathogens involved in intramammary infection (IMI) is basic 
to knowledge of the disease and the design of mastitis control programs. In dairy industry, the economic impact of both clinical and subclinical forms of mastitis is large as losses occur from decreased milk production due to reduced its quality and price, treatment and labor costs, veterinary fees, increased risk of subsequent mastitis and increased risk of culling or death of the animal (Harmon, 1994). Furthermore, SCM remains an important cause of reduced milk production and poor quality of products such as cheese or casein (Roux, et al., 1995). Diagnosis of acute mastitis presents little difficulty as compared to subclinical by ordinary clinical tests. Also, more attention has been given for the diagnosis of SCM by indirect tests (Joshi, et al., 1976). Bacteriological culture is a test, similar to the CMT and Somatic cell count (SCC), which are extremely useful tools for monitoring udder health status and for problem-solving (Radostits, et al., 1994). Simply the bacteriological culture of milk is essential to determine the presence and type of pathogen involved in cases of IMI. Some studies have identified the main pathogenic organisms responsible for SCM in small ruminant (Marco, 1994 and Las Heras, et al., 1999). They found that the most prevalent etiological group is represented by staphylococci and particularly Staph. aureus, CNS, Str. pyogenes and Str. agalactiae. In mastitic milk from severe clinical mastitis, the gross abnormalities of milk are readily observed and milk is discarded by the producers. Such milk normally would not enter the food chain, but with SCM infected milk with no visible changes accidentally mixed into bulk milk and also enters food chain and poses a human health hazards. Although pasteurization is likely to destroy all human pathogens, there is concern when raw milk is consumed or when pasteurization is faulty. As a result of the economic and public health significance of SCM, the objective of this work was to detect its prevalence in goats and sheep by using screening tests and microbiological examination.

\section{MATERIALS and METHODS}

\section{Milk samples:}

A total number of 395 milk samples were collected from apparently healthy she-goats and ewes at different localities in Assiut Governorate, comprising 197 halves of milk samples from 100 lactating she-goats and 198 halves of milk samples from 100 lactating ewes.

\section{I- Screening tests to detect SCM:}

a- CMT as described by Schalm, et al. (1971).

b- MWST according to Murphy and Hanson (1941). 


\section{II- Microbiological examination of SCM milk samples:}

a- Isolation of members of Family Enterobacteriaceae according to Finegold and Martin (1982); Collee, et al. (1989); Carter and Cole (1990) and Koneman, et al. (1992).

b- Isolation of Staph. aureus (Bailey and Scott, 1994) .

c- Isolation and identification of Streptococci (Quinn, et al.1994).

d- Isolation and identification of Molds: Fungal cultures were kindly identified by staff members of the Assiut University Mycological Centre (AUMC), Assiut, Egypt, using the following references: KwonChung and Bennett (1992), Moubasher (1993), Odds and Bernaerts (1994) and Hoog, et al. (2000).

\section{RESULTS}

The obtained results were illustrated in Tables 1-6 and Figures 1-2

Table 1: Half-wise incidence of subclinical mastitis in she-goat's and ewe's milk samples based on the results of CMT and MWST.

\begin{tabular}{|c|c|c|c|c|c|}
\hline \multirow{2}{*}{ Type of animal } & \multirow{2}{*}{$\begin{array}{c}\text { No. of } \\
\text { halves }\end{array}$} & \multicolumn{4}{|c|}{ Positive } \\
\cline { 3 - 6 } & & \multicolumn{2}{|c|}{ CMT } & \multicolumn{2}{c|}{ MWST } \\
\cline { 3 - 6 } & & No. & $\%$ & No. & $\%$ \\
\hline She-goats & 197 & 68 & 34.52 & 67 & 34.01 \\
\hline Ewes & 198 & 19 & 9.60 & 19 & 9.60 \\
\hline
\end{tabular}

Table 2: Animal-wise incidence of subclinical mastitis in she-goat's and ewe's milk samples based on the result of CMT and MWST.

\begin{tabular}{|c|c|c|c|c|c|}
\hline \multirow{2}{*}{ Type of animal } & \multirow{2}{*}{$\begin{array}{c}\text { No. of } \\
\text { animals }\end{array}$} & \multicolumn{4}{|c|}{ Positive } \\
\cline { 3 - 6 } & & No. & $\%$ & No. & $\%$ \\
\hline She-goats & 100 & 44 & 44 & 44 & 44 \\
\hline Ewes & 100 & 14 & 14 & 14 & 14 \\
\hline
\end{tabular}

Table 3: Quarter-wise incidence of subclinical mastitis in she-goat's and ewe's milk samples based on the results of bacteriological and mycological examinations.

\begin{tabular}{|c|c|c|c|c|c|}
\hline \multirow{2}{*}{$\begin{array}{c}\text { Type of } \\
\text { animal }\end{array}$} & \multirow{2}{*}{$\begin{array}{c}\text { No. of } \\
\text { halves }\end{array}$} & \multicolumn{4}{|c|}{ Positive } \\
\cline { 3 - 6 } & & \multicolumn{2}{|c|}{ Bacteriologically } & \multicolumn{2}{c|}{ Mycologically } \\
\cline { 3 - 6 } & 197 & 30 & $\%$ & No. & $\%$ \\
\hline She-goats & 19.23 & 2 & 1.02 \\
\hline Ewes & 198 & 16 & 8.08 & 0 & 0 \\
\hline
\end{tabular}


Table 4: Animal-wise incidence of subclinical mastitis in she-goat's and ewe's milk samples based on the results of bacteriological and mycological examinations.

\begin{tabular}{|c|c|c|c|c|c|}
\hline \multirow{2}{*}{$\begin{array}{c}\text { Type of } \\
\text { animal }\end{array}$} & \multirow{2}{*}{$\begin{array}{c}\text { No. of } \\
\text { animals }\end{array}$} & \multicolumn{4}{|c|}{ Positive } \\
\cline { 3 - 6 } & & \multicolumn{2}{|c|}{ Bacteriologically } & \multicolumn{2}{c|}{ Mycologically } \\
\cline { 3 - 6 } & 100 & 27 & 27 & 2 & 2 \\
\hline She-goats & 10. & 12 & 12 & 0 & 0 \\
\hline Ewes & 100 & &
\end{tabular}

Table 5: Incidence of the isolated bacteria causing subclinical mastitis in the examined she-goat's and ewe's milk samples.

\begin{tabular}{|c|c|c|c|c|}
\hline \multirow{2}{*}{ Isolated species } & \multicolumn{2}{|c|}{ She-goats } & \multicolumn{2}{|c|}{ Ewes } \\
\cline { 2 - 5 } & No./197 & $\%$ & No./198 & $\%$ \\
\hline Staph. aureus & 13 & 6.60 & 8 & 4.04 \\
*CNS & 12 & 6.09 & 9 & 4.55 \\
Str. pyogenes & 2 & 1.02 & 1 & 0.51 \\
Str. agalactiae & 2 & 1.02 & 2 & 1.01 \\
E. coli & 2 & 1.02 & 1 & 0.51 \\
Klebsiella pneumoniae & 0 & 0.00 & 1 & 0.51 \\
Enterobacter spp. & 8 & 4.06 & 3 & 1.52 \\
\hline Total & 39 & 19.80 & 25 & 12.65 \\
\hline
\end{tabular}

* Coagulase negative Staphylococci

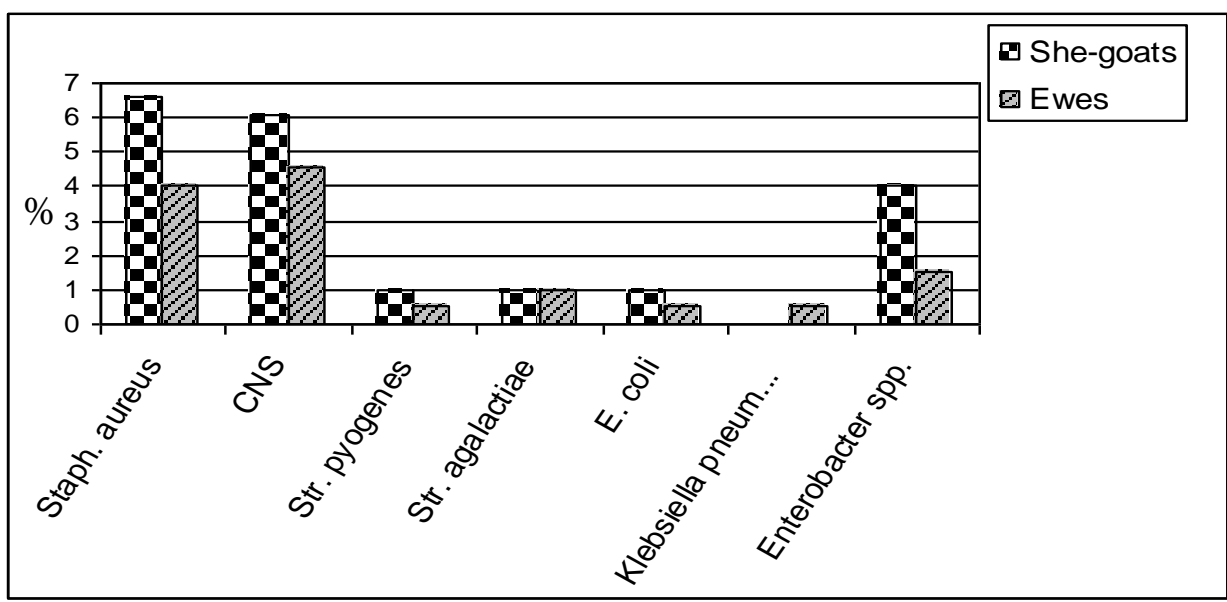

Fig. 1: Incidence of the isolated bacteria causing subclinical mastitis in the examined she-goat's and ewe's milk samples.

$\mathrm{CNS}=$ Coagulase negative Staphylococci 
Table 6: Incidence of the isolated molds causing subclinical mastitis in she-goat's and ewe's milk samples.

\begin{tabular}{|c|c|c|c|c|}
\hline \multirow{2}{*}{ Isolated fungi } & \multicolumn{2}{|c|}{ She-goats } & \multicolumn{2}{c|}{ Ewes } \\
\cline { 2 - 5 } & No. & $\%$ & No. & $\%$ \\
\hline Aspergillus fumigatus Fresenius & 1 & 0.51 & 0 & 0.0 \\
Aspergillus terreus Thom & 1 & 0.51 & 0 & 0.0 \\
\hline Total & 2 & 1.02 & 0 & 0.0 \\
\hline
\end{tabular}

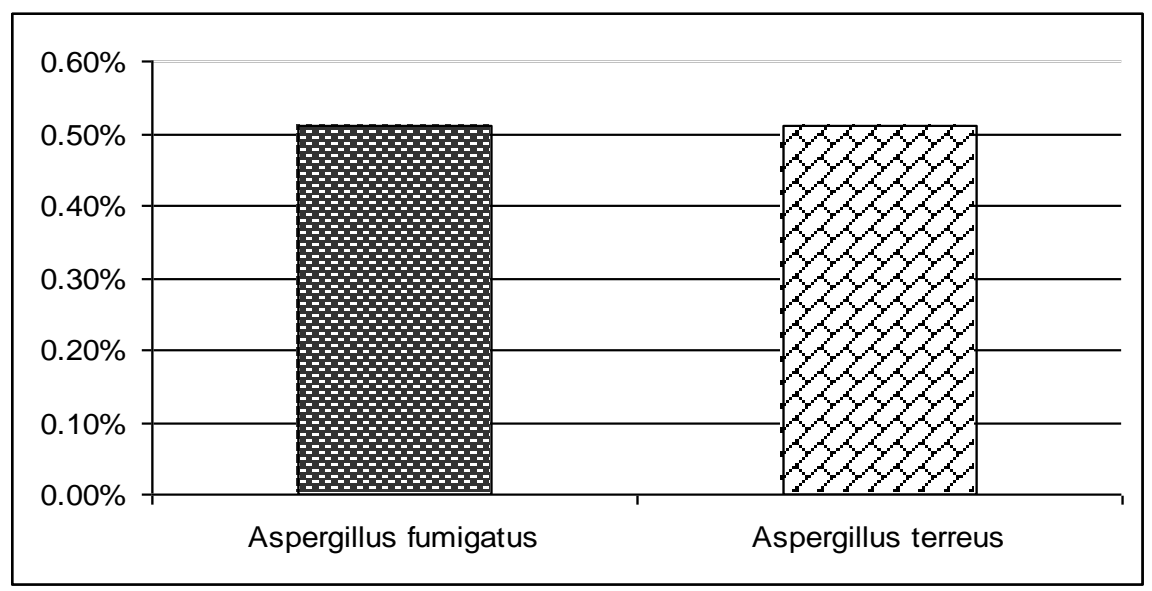

Fig. 2: Incidence of the isolated molds causing subclinical mastitis in she-goat's and ewe's milk samples.

\section{DISCUSSION}

\section{I- Screening tests for detection of SCM:}

Data presented in Table 1 showed that out of 197 halves shegoat's milk samples examined by CMT, 68 (34.52\%) were positive. Extremely lower results were estimated by Salem, et al. (1993) (9.56\%) and Hassanain \& Zaabal (2004) (1.66\%), however, higher percentage was recorded by Guha, et al. (1989) (48.44\%). With regard to ewe's milk, out of 198 halves examined, 19 samples (9.60\%) were positive. Somewhat, similar result was estimated by Salem, et al. (1993) $(10.11 \%)$, while, Moawad and Osman (2005) stated extremely higher incidence of 55.6\%. Regarding MWST it was found that 67 samples (34.01\%) of she-goat's milk samples were positive and extremely lower result was reported by Salem, et al. (1993) (8.47\%) while, higher result was stated by Guha, et al. (1989) (57.8\%). Concerning ewe's milk samples, 19 samples $(9.60 \%)$ were positive while, Salem, et al. (1993) estimated lower percentage $(7.81 \%)$. 
The animal-wise incidence of SCM in she-goat's and ewe's milk samples based on the result of CMT and MWST was illustrated in Table 2. Out of each 100 she-goat's and ewes examined, 44 animals (44\%) \& $14(14 \%)$ were positive, respectively. Higher results with a great extent in ewes stated by Al-Hawary (2005) and Moawad \& Osman (2005) (26.7 and 53.98\%), respectively.

\section{II- Microbiological examination of milk for detection of SCM:}

The half-wise incidence of SCM in she-goat's and ewe's milk samples based on the result of bacteriological and mycological examination was illustrated in Table 3. 30 (15.23\%) of examined shegoat's halves, were bacteriologically positive and extremely higher results were estimated by Salem, et al. (1993) (79.36\%) and Hassanain \& Zaabal (2004) (20\%). In case of ewe's halves, 16 (8.08\%) were positive and $182(91.22 \%)$ were negative. Extremely higher result was incriminated by Salem, et al. (1993) (80.45\%). Additionally, it was found that two halves $(1.02 \%)$ of she goats halves examined mycologically were positive however; in ewes no half gave positive result.

The obtained results in Table 4 revealed the animal-wise incidence of SCM based on the result of bacteriological and mycological examination. Out of 100 she-goats examined bacteriologically, 27 animals (27\%) were positive. Somewhat lower result was recorded by Hassanain \& Zaabal (2004) (23.33\%). While, in ewes 12 animals (12\%) were positive. Moreover, 2 (2\%) of she-goats animals were mycologically positive, but in case of ewes, animals gave negative results.

Staph. aureus were isolated from she-goat's milk samples in $13(6.60 \%)$ and this is higher than that obtained by Salem, et al. (1993) (3.7\%). However, extremely higher incidences were recorded by Mishra, et al. (1996) (22.7\%) and Hassanain \& Zaabal (2004) (58.33\%). Concerning CNS, 12 isolates $(6.09 \%)$ were recovered and relatively higher incidence of $11.36 \%$ was estimated by Mishra, et al. (1996). Two species $(1.02 \%)$ each of Str. pyogenes and Str. agalactiae were recovered in relatively similar result of Salem, et al. (1993) (1.6\%). Also, $2(1.02 \%)$ isolates of E. coli was isolated and it is somewhat higher than that stated by Salem, et al. (1993) (0.623\%). However, higher results were recorded by Guha, et al. (1989), Mishra, et al. (1993), Hassanain \& Zaabal (2004) and Bayoumi, et al. (2005) (5.26, 9.09, 41.67 and $15 \%$, respectively). In addition, 8 strains (4.06\%) of Ent. spp. were isolated. In examined ewe's milk samples, 8 isolates (4.04\%) of 
Staph. aureus were obtained and Salem, et al. (1993) stated lower incidence of $1 \%$. Moreover, extremely higher results were stated by Moawad \& Osman (2005) (30.65\%) and Al-Hawary (2005) (84.38\%). Concerning CNS, 9 isolates $(4.55 \%)$ and one isolate $(0.51 \%)$ of Str. pyogenes were recovered. Moreover, 2 strains $(1.01 \%)$ of Str. agalactiae were isolated in lower incidences than that reported by Moawad and Osman (2005) (7.69\%). Also, one strain (0.51\%) of E. coli was isolated and this is lower than that estimated by Salem, et al. (1993) (1.2\%) and Moawad \& Osman (2005) (14.10\%). Klebsiella pneumoniae and Ent. spp. were isolated in percentages of 0.51 and $1.52 \%$, respectively, as shown in Table 5 and Fig. 1. It is clear that, Staph. aureus was the highest microorganism isolated from she-goat's and ewe's milk samples. This could be attributed to the capacity of this microorganism to produce exo-polysaccharides (slime), which form a protective barrier that restricts the efficiency of both immune responses and chemotherapy (Baselga, et al., 1994).

Results illustrated in Table 6 and Fig. 2 showed that one mold isolate $(0.51 \%)$ of each Aspergillus fumigatus and A. terreus were recovered from she-goat's milk samples, however, no yeasts were obtained. On the contrary neither yeast nor mold could be isolated from ewe's milk samples.

Under the condition of this investigation, it can be concluded that, CMT and MWST were highly sensitive for detection of SCM and their application lead to earlier detection of infected animal and its isolation either for culling or therapy. Staphylococci either Staph. aureus or CNS were the most causative agents causing SCM followed by Ent. spp. Ewes more resist to mycotic SCM than goats.

\section{REFERENCES}

Al-Hawary, I.I. (2005): Incidence of Staph. aureus and Pseudomonas organisms in SC mastitic free sheep milk. Proc. $4^{\text {th }}$ Int. Sci. Conf., Mansoura Univ., Egypt, pp. 35-44.

Bailey, W.R. and Scott, E.G. (1994): "Diagnostic Microbiology". A text book for the isolation and identification of pathogenic microorganisms. $9^{\text {th }}$ Ed., the C.V. Mosby, St. Louis.

Baselga, R.; Albizu, I. and Amorena, B. (1994): Staph. aureus paramecapsule and slime as virulence factors in ruminant mastitis. A review. Vet. Microbiol., 39 (3-4): 195-204. 
Bayoumi, Faten, S.; Zaki, Mona, S.; Nasr, Soad, M. and Hind, M.G. (2005): Some microbiological and clinicopathological studies on she-goats suffering from SCM. J. Egypt. Vet. Med. Assoc., 65 (1): 189-199.

Carter, G.R. and Cole, Jr.R. (1990): "Diagnostic Procedures in Veterinary Bacteriology and Mycology". $5^{\text {th }}$ Ed., Academic Press., Inc. Harcourt Brace Jovanovich, Publ.

Collee, J.G.; Duggid, J.P.; Fraser, A.G. and Marmion, B.P. (1989): "Practical Medical Microbiology". 13 ${ }^{\text {th }}$ Ed., reprint International Student Ed., Churchill Livingstone and Edinburgh London and New York.

Finegold, S.M. and Martin, W.J. (1982): "Diagnostic Microbiology". $6^{\text {th }}$ Ed., C.V Mosby Co., St. Louis, Toronto, London.

Gonzalo, C. (1996): Physiological and pathological thresholds of SCCs in ewe milk. Small Ruminant Res., 62 (1-2): 27-31.

Guha, C.; Pramanik, A.K.; Misra, S.K. and Banerjee, A.K. (1989): Studies on the incidence and diagnosis of SC and clinical mastitis in goats and in vitro sensitivity of the isolated pathogens. Indian Vet. J., 66 (7): 601-604.

Harmon, R.J. (1994): Mastitis and genetic evaluation for SCC, physiology of mastitis and factors affecting of SCC. J. Dairy Sci., 77: 2103-2112.

Hassanain, Nawal, A. and Zaabal, M.M. (2004): Some microbiological and genetical studies on SCM in baladi goats with emphasis on gene marker. J. Egypt. Vet. Med. Assoc., 64 (1): 235-245.

Hoog, C.S.de.; Guarro, J.; Genè. J. and Figuerans, M.J. (2000): Atlas of Clinical Fungi. Centraalbureau voor Schimmelcalfures. Utrecht, the Netherlands, $1125 \mathrm{pp}$.

Joshi, S.V.; Prasad, J. and Rekib, A. (1976): Studies on the field diagnosis of SCM. Indian Vet. J., 53 (10): 752-756.

Koneman, E.W.; Allen, S.D.; Janda, W.M.; Schreckenberger, P.C. and Winn, W.C. (1992): Color Atlas and Textbook of Diagnostic Microbiology. $4^{\text {th }}$ Ed., R. Winters (ed.), Lippincott Company, Philadelphia.

Kwon-Chung, K.J. and Bennett, J.W. (1992): Medical Mycology. Lea \& Febiger, Philadelphia, $861 \mathrm{pp}$.

Las Heras, A.; Domi'nguez, L.; and Fernández-Garayzábal, J.F. (1999): Prevalence and etiology of SCM in dairy ewes of Madrid region. Small Ruminant Res., 1720:1-9. 
Marco, J.C. (1994): Mastitis en la oveja Latxa: Epidemiologi'a, diagno'sticoy control Ph.D. Thesis, Univ. Zaragoza, Spain.

Mishra, P.R.; Hazari, S. and Pal, A. (1996): SCM in goat with special reference to fungus. Indian J. Dairy Sci., 49 (3): 209-210.

Moawad, A.A. and Osman, S.A. (2005): Prevalence and etiology of SCM in dairy ewes at Fayoum Governorate, Egypt. Assiut Vet. Med. J., 51 (107): 135-149.

Moubasher, A.H. (1993): Fungi in Qatar and other Arab countries. The Centre of Scientific and Applied Research, University of Qatar, Doha, Qatar.

Murphy, J.M. and Hanson, J.J. (1941): A modified whiteside test for the detection of chronic bovine mastitis. Cornell Vet., 31: 47-55.

Odds, F.C. and Bernaerts, R. (1994): CHROMagar candida, a new differential isolation medium for presumptive identification of clinically important Candida species. J. Clin. Microbiol., 32 (8): 1923-1929.

Quinn, P.J.; Garter, M.E.; Markey, B.A. and Carter, G.R. (1994): Clinical Veterinary Microbiology. Wolfe Publ., an imprint of Mosby Year Book Europe Limited.

Radostits, O.M.; Lesli,e K.E. and Fetrow, J. (1994): Herd Health: Food Animal Production Medicine. $2^{\text {nd }}$ Ed., Toronto: W.B. Saunders Company, 229-273.

Roux, Y.L.; Colin, O. and Laurent, F. (1995): Proteolysis in samples of quarter milk with varying somatic cell counts. Comparison of some indications of endogenous proteolysis in milk. J. Dairy Sci., 78 (6): 1289-1297.

Salem, A.A.; Saad, Marcel; El-Ebeedy, A. and Zaki, Mervat, A. (1993): Some studies on SCM in sheep and goats. J. Egypt. Vet. Med. Assoc., 53 (1\&2): 261-265.

Schalm, O.W.; Carrolle, J. and Jain, N.C. (1971): Bovine mastitis. Lea and Febiger Philadelphia. 